\title{
Negócios jurídicos processuais: o controle dos atos processuais pelas partes no sistema processual civil brasileiro
}

\author{
The control of procedural acts by the parties in the brazilian civil procedural system
}

\author{
(iD) Luiz Gustavo Tiroli \\ Universidade Estadual de Londrina (UEL) \\ Graduando em Direito (UEL) \\ Londrina / Paraná / Brasil \\ luiz.gustavo.tiroli@uel.br \\ Rafael Gomiero Pitta \\ Faculdades Londrina \\ Doutor em Ciências Jurídicas \\ Professor e Coordenador do Núcleo de Práticas Jurídicas \\ Londrina/PR/Brasil \\ rafapitta22@gmail.com
}

Resumo: Os negócios jurídicos processuais atípicos, previstos em cláusula aberta no art. 190 do Código de Processo Civil brasileiro constituem inovação na ordem jurídica ao possibilitar que as partes convencionem acerca de ônus probatório, agenda processual, delimitação de questões e utilização dos meios de prova. Neste sentido, o diploma legal alterou a dinâmica do case management ao atribuir maior responsabilidade aos litigantes na resolução do conflito, democratizando o procedimento e tornando-o mais eficaz ao admitir negócios processuais atípicos que se adequem de acordo com a realidade e a especificidade do caso concreto. O método adotado na produção do artigo é o dedutivo, aliado à técnica de revisão bibliográfica. Objetiva-se analisar a influência do princípio da autonomia privada no caráter publicista do processo civil, perquirindo sobre a necessária relativização da dicotomia entre o direito público e o direito privado a fim de concretizar um processo democrático e efetivo, à luz da axiologia constitucional.

Palavras-chave: negócios jurídicos processuais; autonomia privada; processo civil.

Abstract: The atypical contractualized procedures, provided for in the art. 190 of the Brazilian Civil Procedure Code, produce innovation in the legal order and allow the parties to make procedural arrangements on evidential burden of proof, procedural agenda, delimitation of issues and use of evidence. Thus, the legal diploma has changed the case management to assign more responsibility to the parties in the resolution of conflicts, democratizing the procedure and making it more effective to admit atypical procedural arrangements that are in accordance with the reality and specificity of the case. This research adopted the deductive method, combined with a bibliographic review technique. The goal of this article is to analyze the influence of the principle of private autonomy in the public character of the civil process, demanding the relativization required by the dichotomy between public and private law, poiting to the implementation of a democratic and effective civil procedure, in the light of constitutional axiology.

Keywords: contractualized procedures; private autonomy; civil procedure.

\section{Para citar este artigo}

ABNT NBR 6023:2018

TIROLI, Luiz Gustavo; PITTA, Rafael Gomiero. Negócios jurídicos processuais: o controle dos atos processuais pelas partes no sistema processual civil brasileiro. Prisma Jurídico, São Paulo, v. 20, n. 1, p. 135-152, jan./jun. 2021.

http://doi.org/10.5585/prismaj.v20n1.17647. 


\section{Introdução}

A legislação processual brasileira passou a atribuir, a partir do Código de Processo Civil de 2015, maior destaque e importância à possibilidade da celebração de negócios jurídicos processuais entre as partes, trazendo à baila a possibilidade de celebração de negócios processuais atípicos, regulados em cláusula aberta no art. 190, sinalizando para a autonomia privada relativa e limitada no publicismo processual, garantindo aos litigantes uma participação ativa e democrática na condução do procedimento, efetivando, de acordo com o caso concreto, a prestação jurisdicional mais adequada.

Apesar de não ser novidade no ordenamento brasileiro, o tratamento atribuído pelo atual diploma processual à autonomia privada das partes no âmbito das regras processuais ampliou consideravelmente as possibilidades para que se crie regulamentação específica à solução de seus litígios de forma mais livre e adequada, desde que obedecidos os parâmetros legais estabelecidos pela lei processual.

O presente artigo explora as possibilidades de negócio jurídico já contempladas pela lei processual brasileira e sugere uma ampliação no sentido de permitir que as partes tenham cada vez mais liberdade para conduzir atos processuais e estabelecer regras de acordo com as características específicas do litígio.

Para esta análise, foi utilizado no presente estudo o procedimento metodológico hipotético-dedutivo, uma vez que parte da descrição das possibilidades atuais para ao final sugerir alterações no sentido de otimizar os instrumentos de negociação processual (LAKATOS; MARCONI, 2009, p. 99).

Ainda, discorre sobre possibilidades atuais e avalia a aplicação da axiologia constitucional no processo civil, a incidência da autonomia privada no caráter publicista e a importância dos negócios jurídicos processuais atípicos para a democratização do processo.

O presente trabalho realiza revisão bibliográfica pertinente ao assunto objetivando discorrer sobre a influência do princípio da autonomia privada no caráter publicista do processo civil, perquirindo sobre a necessária relativização da dicotomia entre o direito público e o direito privado a fim de concretizar um processo democrático e efetivo à luz dos princípios e valores entabulados na Constituição.

Na consecução do objetivo acima delineado, o trabalho está dividido em três tópicos. O primeiro versa sobre o Código de Processo Civil de 2015 e o processo de constitucionalização do direito processual brasileiro, tratando da guinada valorativa do ordenamento jurídico que, outrora vinculado ao Código Civil, hodiernamente se funda na Constituição Federal e encontra 
nela um vetor hermenêutico, aplicando nas relações privadas e nos procedimentos a axiologia constitucional. Tal perceptiva exige que o processo civil seja concebido e interpretado à luz dos princípios irradiados do texto constitucional, de modo a cumprir, em última instância, os valores sociais elegidos na Constituição Federal.

O segundo trata sobre a influência da autonomia privada no caráter publicista do processo civil, no sentido de possibilitar maior participação das partes na condução do processo, em que os reais interessados na causa possam estabelecer mecanismos mais eficazes na condução do procedimento em face das peculiaridades do caso concreto.

Não se trata, simplesmente, de importar princípios do direito privado para o processo cível. Faz-se necessário, antes disso, compreender que o procedimento impacta na qualidade da prestação jurisdicional de ordem pública, devendo a influência do referido princípio ser efetiva, porém limitada, condicionada às normas cogentes e aos princípios constitucionais e processuais do ordenamento pátrio.

Por fim, a celebração de negócios jurídicos processuais atípicos visa contribuir para a ampliação do controle dos atos processuais pelas partes no sistema processual civil brasileiro, respeitando os limites impostos pela codificação e pela principiologia constitucional. Tal avença contribui para um processo de democratização e efetivação do processo, a fim de atingir a resolução da lide, a prestação jurisdicional adequada ao caso concreto e o acesso à justiça dentro de um tempo razoável.

\section{O CPC/2015 e a constitucionalização do direito processual civil brasileiro}

Os movimentos de constitucionalização de direitos se deram em momentos distintos da história, o mais recente deles se inicia após a Segunda Guerra Mundial e ganha relevo em diferentes ordenamentos jurídicos pelo mundo. No Brasil, especificamente, o fim da ditadura militar e os movimentos que culminaram com a promulgação da Constituição Federal de 1988 abriram caminhos para a constitucionalização de relações jurídicas diversas.

A constitucionalização do direito enquanto fenômeno pode ser compreendida como "poder de conformação que se reconhece na Constituição em relação às demais representações normativas", ou seja, os diplomas infraconstitucionais não são constituídos somente nos limites da Constituição, mas sobretudo em harmonia com sua axiologia, em conformidade com valores e princípios estabelecidos pela sociedade na consolidação do Estado (TAVARES, 2006, p. 134).

Assim sendo, está superada a concepção de Carta Fundamental enquanto limitadora da atividade legislativa, dando vazão a uma compreensão mais ampla, ou seja, de uma Constituição 
enquanto vetor hermenêutico e axiológico para construção e interpretação do ordenamento infraconstitucional, verdadeiro centro unificador.

o respeito à Constituição, fonte suprema, implica não somente a observância de certos procedimentos para emanar a norma (infraconstitucional), mas, também a necessidade de que o seu conteúdo atenda valores presentes (e organizados) na própria Constituição (PERLINGIERI, 2002, p. 10).

Deste modo, o direito privado, outrora pareado ao direito público, sobretudo no modelo de sociedade liberal em que o papel da Constituição era garantir as liberdades individuais e afastar a ingerência estatal, hodiernamente passou a ser concebido a partir da Constituição (LIMA; CAMBI, 2015, p. 158).

A constitucionalização determina que a integralidade do ordenamento infraconstitucional seja filtrado sob a perspectiva e crivo constitucional, inclusive o processo civil, que positivou tal perspectiva na abertura do Código de Processo Civil de 2015, no artigo $1^{\circ}$, onde lê-se: "o processo civil será ordenado, disciplinado e interpretado conforme os valores e as normas fundamentais estabelecidos na Constituição da República Federativa do Brasil, observando-se as disposições deste Código" (BRASIL, 2015).

Ainda neste sentido, a exposição de motivos do diploma processual de 2015 apresentado pelo ministro Luiz Fux ao presidente do Senado José Sarney em 08 de junho de 2010 representa a intenção dos processualistas em adequar e harmonizar a norma processual aos valores encartados no texto constitucional, na tentativa de tornar o processo mais eficiente e efetivo, em conformidade o intuito de resolver conflitos e cumprimento da lei material. ${ }^{1}$

O publicismo que caracteriza o direito processual civil garante uma intrínseca relação com direito constitucional, e assim vincula aquele aos valores e princípios emanados deste. Sendo assim, a doutrina pátria debate a classificação didática e científica dessa realidade, problematizando se trataria de ser um direito processual constitucional ou direito constitucional processual.

\footnotetext{
${ }^{1}$ Na elaboração deste Anteprojeto de Código de Processo Civil, essa foi uma das linhas principais de trabalho: resolver problemas. Deixar de ver o processo como teoria descomprometida de sua natureza fundamental de método de resolução de conflitos, por meio do qual se realizam valores constitucionais. [...] O novo Código de Processo Civil tem o potencial de gerar um processo mais célere, mais justo, porque mais rente às necessidades sociais e muito menos complexo. [...] A coerência substancial há de ser vista como objetivo fundamental, todavia, e mantida em termos absolutos, no que tange à Constituição Federal da República. Afinal, é na lei ordinária e em outras normas de escalão inferior que se explicita a promessa de realização dos valores encampados pelos princípios constitucionais. [...] A necessidade de que fique evidente a harmonia da lei ordinária em relação à Constituição Federal da República fez com que se incluíssem no Código, expressamente, princípios constitucionais, na sua versão processual. [...] Trata-se de uma forma de tornar o processo mais eficiente e efetivo, o que significa, indubitavelmente, aproximá-lo da Constituição Federal, em cujas entrelinhas se lê que o processo deve assegurar o cumprimento da lei material.
} 
Nessa esteira, Ada Pellegrini Grinover, ao lado de Cândido Rangel Dinamarco e Antônio Carlos de Araújo Cintra sustentam que não se trata de um ramo autônomo dentro da realidade civil processual, mas uma opção metodológica de aplicação, numa determinada tutela constitucional do processo (GRINOVER; CINTRA; DINAMARCO, 2008, p. 85).

\begin{abstract}
Direito processual constitucional é um método consistente em examinar o sistema processual e os institutos do processo à luz da Constituição e das relações mantidas com ela. Não é mais um entre os diversos ramos do direito processual, como o direito processual civil, o trabalhista, o penal etc. O método constitucionalista inclui o estudo das recíprocas influências existentes entre Constituição e processo - relações que se expressam na tutela constitucional do processo, representada pelos princípios e garantias que, vindos da Constituição, ditam padrões políticos para a vida daquele. Ao se conceber e interpretar os institutos de direito processual, portanto, os princípios constitucionais devem sempre ser tomados como superiores premissas de todo o sistema, ponderando-se a importância concreta de cada um e buscando uma solução que, na medida do possível, confira a máxima efetividade a todos eles (DINAMARCO; LOPES, 2019, p. 53).
\end{abstract}

Desta forma, "existe um direito constitucional processual, para significar o conjunto das normas de direito processual previstas na Constituição Federal, ao lado de um direito processual constitucional, que seria a reunião dos princípios para o fim de regular a denominada jurisdição constitucional” (NERY JUNIOR, 1996, p. 19).

À margem da distinção didática, importa sobretudo a percepção do processo como instrumento a serviço da ordem constitucional, construindo uma doutrina que vislumbre a igualdade, a dignidade da pessoa humana, a primazia de mérito, a legalidade, a responsabilidade, e sobretudo a participação dos agentes envolvidos no litígio, consagrada nos princípios do contraditório e ampla defesa.

Entretanto, a constitucionalização não significa, pelo menos em princípio, uma tendência da doutrina em semear uma maior flexibilização ou um maior grau de informalidade aos atos processuais, mas um processo voltado para o alcance de eficiência na solução de conflitos, estando em consonância com a axiologia constitucional no âmbito processual, pois se verifica a tendência constitucional relacionada ao princípio da celeridade e do acesso à justiça, sendo seu arcabouço menos preocupado em obstaculizar o alcance de resultados pela aplicação de regras restritivas.

A celeridade processual e o acesso à justiça possibilitam uma retomada da participação das partes na celebração de negócios processuais jurídicos atípicos, evidentemente limitados por outros valores igualmente irradiados da axiologia constitucional e pelas normas cogentes.

Em face dos mesmos princípios constitucionais acima referidos, não seria plausível determinar uma autonomia privada ilimitada, uma mera importação do instituto do âmbito civil para o processual que desconsiderasse as implicações sociais, sobretudo pelas especificidades 
limitadoras que constam no art. 190, parágrafo único do Código de Processo Civil de 2015, ao disciplinar que, havendo casos de nulidade, inserção abusiva em contrato de adesão ou em que alguma parte encontra-se em situação de vulnerabilidade, o juízo, na análise do caso concreto, deverá indeferir e afastar a validade do negócio jurídico processual (CABRAL, 2015, p. 92).

Sendo assim, a partir da proteção conferida pelo arcabouço constitucional, tem-se o respaldo para a concretização de negócios jurídicos processuais atípicos, no intuito de cumprir os princípios de celeridade e acesso à justiça, convocando para o cerne do litígio os interessados na resolução dos conflitos e na apreciação do mérito, desde que observados a igualdade, a dignidade humana e o devido processo legal.

\section{A influência do princípio da autonomia privada nas relações processuais}

As normas processuais são de ordem pública, portanto, se prestam a regulamentar a relação processual entre as partes e destas com o exercício da jurisdição. Dito isto, o que se pretende no presente estudo não é sugerir a implantação da autonomia privada - característica essencial do direito aplicável às relações cíveis- no ordenamento processual. O que se pretende, de fato, é permitir, em um ambiente de controle, que as partes tenham maior amplitude e liberdade de escolha no âmbito das relações processuais, desde que mantidos os princípios e o equilíbrio processual.

A autonomia privada pode ser utilizada no âmbito do processo civil no sentido de possibilitar maior participação das partes na condução do processo, de modo que os reais interessados na causa possam estabelecer mecanismos mais eficazes na condução do procedimento em face das peculiaridades do caso concreto. Vislumbra-se, assim, uma relativização na dicotomia entre o direito público e o direito privado, a fim de efetivar o princípio da autonomia privada ante o caráter publicista do processo civil.

A relativização da referida dicotomia não significa, como já dito acima, uma desconfiguração do direito processual civil como matéria de direito público, no dizer de Dinamarco:

Essas aberturas para o reconhecimento da configurabilidade de negócios jurídicos processuais segundo o vigente direito positivo brasileiro não chegam ao ponto de desnaturar a visão geral do processo como categoria jurídicos processuais $(2016$, p. 189).

Neste contexto, a dicotomia entre direito público, enquanto responsável por tutelar os interesses coletivos, sociais e difusos, garantindo a supremacia do Estado; e o direito privado, que visa proteger os interesses dos indivíduos e suas relações em comum havendo condições 
de igualdade entre as partes, se consolidou ao longo dos períodos históricos do desenvolvimento do direito, visando "delimitar ao máximo os espaços de intervenção do Estado e os espaços de atuação privada. Uma vez que a divisão entre esses dois ramos era fundamental para a organização do direito, do Estado e da sociedade (BORGES, 2005, p. 74).

Entre a autonomia da vontade e a autonomia privada existe uma distinção tênue que consiste no fato de que a autonomia da vontade se estabelece acima da vontade psicológica dos sujeitos, gerando por si só efeitos jurídicos, o que não ocorre na autonomia privada, conforme Luigi Ferri "las dos expressiones podrían parecer a primera vista sinónimas, pero no lo son" (2001, p. 5). Para Francisco Amaral (2012, p. 183), a autonomia da vontade consiste na possibilidade do agente "praticar um ato jurídico, determinando-lhe o conteúdo, a forma e seus efeitos", enquanto que autonomia privada está relacionada ao "poder que o particular tem de criar, nos limites legais, normas jurídicas".

Deste modo, a autonomia privada consubstancia a determinação de que a vontade livremente manifesta, concretizada no acordo, deve ser cumprida. Entretanto, contemporaneamente entende-se que nem sempre aquele que contrata, o faz porque quer, mas em muitos casos, estabelece a obrigação porque necessita, o que faz com que sejam necessários princípios limitadores dessa liberdade de celebrar negócios jurídicos processuais a fim de proteger as partes, por vezes, delas mesmas (SCHREIBER, 2019, p. 421).

Neste sentido, a noção privatista do direito civil poderá ser aplicada à realidade publica processual, de modo que as partes possam convencionar negócios jurídicos processuais e adequar, à realidade do caso concreto, os procedimentos a serem adotados para uma prestação jurisdicional mais efetiva. Entretanto, assim como ocorre no direito civil, a autonomia privada no âmbito processual não pode ser absoluta, prevalece o acordado, desde que contemplados os pressupostos da legalidade, nos limites do código e da principiologia constitucional, numa espécie de autonomia relativizada, mas que possa contribuir para a concretização do princípio da eficiência e que combata a morosidade da justiça.

Nesta conjectura, a possibilidade de negócios jurídicos processuais se dá desde a fixação de obrigações e sansões até a aplicação de prazos de qualquer natureza, a dispensa de assistentes técnicos e de execução provisória, além da dispensa do efeito suspensivo da apelação. A inserção da autonomia privada na esfera processual denota a intencionalidade do legislador em atribuir caráter democrático ao procedimento, de modo a ajustá-lo às suas pretensões.

O poder conferido às partes não caracteriza necessariamente o fim do caráter público do processo civil, mas demonstra que, como destinatárias da prestação jurisdicional e em 
determinadas situações, elas possam ser mais habilitadas do que o juízo para deliberar sobre os rumos do procedimento "e estabelecer providências em consonância com os escopos publicísticos do processo civil, atinentes à tutela da paz social e à preservação da ordem pública" (PONTE, 2015, p. 311).

José Carlos Barbosa Moreira (1984, p. 2-3) já há muito tempo sustentava que “[...] predomina a tese da admissibilidade de convenções não autorizadas expressis verbis na lei”, muito embora houvesse o entendimento de que no processo (ramo do direito público) a autonomia privada não possui atuação tão ampla como no direito privado.

Todavia, em que pese os institutos mitigarem a autonomia privada em face dos princípios limitadores, não se pode afastar completamente a relevância social de tal instituto, considerando o próprio processo de desenvolvimento da sociedade. Neste aspecto, os negócios jurídicos processuais constituem-se em mecanismos efetivos de construção da autonomia privada no processo, atribuindo responsabilidade aos litigantes na resolução do conflito.

Ressalta-se que não se trata de sustentar o ingresso inadvertido do privatismo característico das relações civis nas relações processuais. Diversamente, a ideia é que, dentro do ambiente e das regras estatais, as partes desfrutem de uma ampla liberdade vigiada e controlada.

\section{A celebração de negócios processuais atípicos: a ampliação do controle dos atos processuais pelas partes no sistema processual civil brasileiro}

Os negócios processuais são fatos jurídicos voluntários em que as partes, no decorrer do processo ou em fase pré-processual, detém a liberdade para deliberar sobre ônus da prova, poderes, faculdades e deveres processuais, alterando o disposto pelo ordenamento jurídico brasileiro através do Código de Processo Civil, e adequando assim o desenvolvimento do procedimento à realidade e às especificidades do caso concreto, de modo a ser eficaz independente de qualquer homologação judicial, conforme artigo 200, caput, do CPC/15, todavia compete ao juiz realizar o controle de validade, analisando os requisitos formais exigidos pelo diploma no artigo 190, parágrafo único.

Pedro Henrique Nogueira (2016, p. 121) define negócio jurídico processual como "o fato jurídico voluntário em cujo suporte fático este, a conferido ao respectivo sujeito o poder de escolher a categoria jurídica ou estabelecer, dentro dos limites fixados no próprio ordenamento jurídico, certas situações jurídicas processuais".

Os negócios processuais que se encontram positivados e que possuem previsão normativa expressa no diploma legal são denominados típicos. Dentre as possibilidades 
prescritas, destaca-se a eleição negocial do foro (art. 63, CPC) e o estabelecimento de calendário processual próprio, de modo que as partes podem, em face dos prazos legais estabelecidos no Código de Processo Civil, modificar e fixar datas específicas para o cumprimento das diligências e etapas processuais (art. 191, $\S \S 1^{\circ}$ e $2^{\circ}, \mathrm{CPC}$ ).

Observe-se que as previsões legais contemplam situações absolutamente corriqueiras e que não implicam, na prática, em uma possibilidade de negociação ou disposição de atos processuais de maior importância entre as partes, tais como controle judicial sobre atos processuais diretamente relacionados aos meios de prova.

A título de exemplo, não é possível às partes, ao menos em tese, pactuarem a proibição recíproca de produção de determinada prova, ou de utilização de um determinado meio de prova, como a prova pericial. Melhor dizendo, o pacto nesse sentido é possível, entretanto, ele não teria efeito algum se o juízo determinasse a produção da prova dispensada pelas partes.

A possibilidade de proibição de produção de prova ou utilização de meios de prova coloca o exercício da jurisdição em posição delicada, afinal, dessa maneira corre-se o risco do juízo ser restringido em sua busca pela verdade dos fatos, transformando o juiz em um burocrata e o processo em um território privado.

Além dos casos acima referidos, é facultado às partes que negociem a respeito da prática de outros atos jurídicos, entre eles a renúncia de prazo (art. 225, CPC), a conversão sobre o ônus da prova (art. 373, $\S 3^{\circ}$ e $4^{\circ}, \mathrm{CPC}$ ), a escolha consensual do perito (art. 471, CPC), o acordo de escolha do arbitramento como técnica de liquidação (art. 509, I, CPC), a desistência do recurso (art. 999, CPC), o pacto de mediação prévia obrigatória (art. $2^{\circ}, \S 1^{\circ}$, Lei n. 13.140/2015), o acordo para a suspensão do processo (art. 313, II, CPC), organização consensual do processo (art. 357, $\S 2^{\circ}$ ), o adiamento negociado da audiência (art. 362, I, CPC), entre outras possibilidades, que privilegiam a autonomia das partes e prioriza sua participação ativa, chamando ambas para a responsabilidade de resolução da lide. (MEDINA, 2017, p. 315).

É compreensível que o código tenha utilizado de cautela em relação aos atos processuais mais importantes, mantendo o controle da maioria deles de forma quase absoluta com o juízo. Entretanto, o momento é adequado para proposição de ampliação de controle de outros atos pelas partes.

As partes poderiam propor contratualmente, por exemplo, a obrigatoriedade de uma fase pré-processual conciliatória e de diálogo visando evitar o ajuizamento e demandas? Poderiam estabelecer o intercâmbio de documentos nesta mesma fase pré-processual? Poderiam abrir mão da possibilidade de apresentação de prova documental para além da fase postulatória, apesar da 
previsão legal do art. 435 CPC? A possibilidade de negociação processual atípica abre margem para essa discussão.

Recentemente o Superior Tribunal de Justiça decidiu questão importante ${ }^{2}$ sobre negócios jurídicos processuais, delimitando a liberdade das partes negociarem antecipadamente e inaudita altera parte medidas expropriatórias/executivas de bloqueio de ativos em caso de inadimplência de cláusula contratual. Decisões futuras deverão conferir maior segurança na utilização do instituto.

Os negócios jurídicos processuais se subdividem em categorias, sendo elas: unilaterais, ou seja, que se manifestam por meio da vontade de uma parte, tais como na possibilidade de renúncia de prazo e desistência da demanda; e negócios jurídicos processuais bilaterais, que dependem da manifestação de vontade das duas partes interessadas no processo, como por exemplo a eleição de foro competente para a resolução da lide que tenha origem a partir do contrato celebrado e a possibilidade jurídica de suspensão convencional do andamento do processo (NEVES, 2016, p. 387).

Os negócios jurídicos processuais bilaterais, por sua vez, subdividem-se em: contratos, considerando que houve manifestação diversa de vontade quanto da celebração do negócio; e acordos ou convenções, quando as vontades se uniram no sentido de construir um objeto de interesse comum para ambos.

Há previsão de negócios plurilaterais, em que há mais de dois sujeitos celebrando o negócio jurídico processual, aliás a participação do juiz caracteriza-o como negócio plurilateral. Cumpre destacar a necessidade de observância das exigências legais do artigo 190 do CPC/15, ainda que os negócios típicos tenham suas próprias regras formais (NEVES, 2016, p. 388).

Dentre as categorias dos negócios jurídicos processuais, destaca-se ainda a espécie dos negócios tácitos, ou seja, que podem ser verificados em comportamentos comissivos, em que a parte concorda tacitamente com a decisão, como pode-se notar no ato incompatível com a vontade de recorrer; ou atos omissivos, quer seja pela omissão, a parte de maneira inerte, não se manifesta, pois o silêncio pode, em certas circunstâncias, normalmente tipicamente previstas, ser uma manifestação de vontade (NEVES, 2016, p. 387).

O Código de Processo Civil de 1973, no art. 125, determinava que o procedimento devia ser conduzido diretamente pelo magistrado, que o impulsiona, desempenhando o papel de protagonista do processo. O Novo Código de Processo Civil de 2015, nesta perspectiva, objetiva conferir às partes uma parcela desse protagonismo, democratizando o processo.

\footnotetext{
${ }^{2}$ STJ - Recurso Especial no 1.810 .444 - Sp (2018/0337644-0) Relator: Ministro Luis Felipe Salomão (aguarda publicação).
} 
A necessidade de um maior protagonismo das partes está ligada a uma constante crescente de complexidade das questões litigiosas a que estão sujeitos aqueles que devem exercer a jurisdição. A complexidade dos atos sociais dentro da dinâmica da modernidade líquida dá ensejo a conflitos cada vez mais específicos (BAUMAN, 2001, p. 47), “considerando a multifacetada gama de ambientes fáticos que podem desembocar no Poder Judiciário" (PONTE, 2015, p. 312).

Neste sentido, disciplina o art. 190 do Código de Processo Civil que as partes, plenamente capazes e de comum acordo, em obediência aos pressupostos exigidos pela legislação civil, podem celebrar negócios jurídicos processuais típicos, sendo aqueles que encontram-se previstos e positivados no referido diploma legal; e atípicos, ou seja, a avença a respeito da realização dos atos processuais em hipóteses não diretamente regulamentadas por lei. A eleição de uma cláusula geral de negociação processual vai ao encontro da tendência francesa (contrat de procédure) e inglesa (case management) (NEVES, 2016, p. 389).

Em breve comparação com sistemas estrangeiros da tradição common law, o case management, oriundo do direito inglês e largamente desenvolvido nos EUA tanto em nível federal como estadual, é o modo como ocorre a condução dos atos processuais naqueles países, o que confere grande liberdade para o desenvolvimento da dinâmica procedimental. A condução de atos processuais em países de tradição common law sempre concentrou a prática de atos anteriores ao julgamento em ambiente extrajudicial sob a supervisão indireta do juiz.

Tanto na Inglaterra como nos EUA, os advogados das partes atuam diretamente na obtenção de provas no âmbito processual, contando com a colaboração de oficiais da corte para atribuir oficialidade aos atos quando for o caso.

Sob a perspectiva estrutural, o common law, na perspectiva do case management concentrado na atividade dos advogados, tem muito a acrescentar aos negócios jurídicos processuais do ordenamento jurídico brasileiro. Esta pesquisa, no entanto, concentra esforços nas possibilidades apresentadas pelos negócios atípicos e sua ampliação.

Voltando à possibilidade de eleição de uma cláusula geral pelas partes, segundo Judith Martins-Costa (1999, p. 58) "a cláusula geral constitui, portanto, uma disposição normativa que utiliza, no seu enunciado, uma linguagem de tessitura intencionalmente "aberta", "fluida" ou "vaga", caracterizando-se pela ampla extensão em seu campo semântico [...]".

Dentre as possibilidades de negócios atípicos, tem-se ainda o acordo para não promover execução provisória, acordo para dispensa de caução em execução provisória, acordo para limitar número de testemunhas, acordo para autorizar intervenção de terceiro fora das hipóteses legais, acordo para decisão por equidade ou baseada em direito estrangeiro ou consuetudinário, 
acordo para tornar ilícita uma prova entre outras possibilidades jurídicas que deverão ser acolhidas ou afastadas na análise do caso concreto pelo juízo competente (DIDIER JUNIOR, 2016, p. 30).

Sendo assim, a concretização de negócios atípicos constitui-se como inovação no ordenamento jurídico brasileiro, pois o Código de Processo Civil de 1973 previa a celebração de negócios processuais típicos, a maioria deles referente a questões de menor importância tais como a eleição convencional do foro, a convenção sobre o ônus da prova, o acordo que versava sobre a suspensão dos atos do procedimento, entre outros que encontram-se disciplinados contemporaneamente no diploma processual (CUNHA, 2016, p. 54). Todavia, não havia a possibilidade de as partes celebrarem negócios processuais fora das hipóteses previstas (DIDIER JUNIOR, 2016, p. 31).

Neste sentido, destaca-se o autorregramento da vontade no processo civil, concebido por parte da doutrina, sobretudo por Fredie Didier Júnior (2015, p. 19-25) e Bruno Garcia Redondo (2015, p. 274) como novo princípio processual, corroborando para uma democratização do procedimento, e contribuindo para a concretização dos princípios constitucionais de acesso à justiça e efetividade.

Pontes de Miranda (1954, p. 56) afirma que, o que caracteriza o autorregramento da vontade é o poder de, com ele, compor o suporte fático dos atos jurídicos com o elemento nuclear da vontade, não importa em que ramo do direito. Todavia, não se pode confundir com a "autonomia da vontade": "[...] porque, com isso, se elidiria, desde a base, qualquer autorregramento da vontade, em direito público, - o que seria falsíssimo" (MIRANDA, 1954, p. 56).

Entretanto, Daniel Amorim Assumpção Neves (2016, p. 389) sustenta que o instrumento encontra-se vinculado à discussões acadêmicas, mas não se vislumbra sua ocorrência na práxis forense. Para tal, faz- necessário uma ressignificação da cultura jurídica, de modo a valorizar a participação das partes na resolução da lide.

Um dos aspectos que poderia contribuir para a concretização dessa perspectiva na prática seria a celebração de negócios processuais atípicos em cláusulas contratuais, anteriormente ao início da demanda, vinculando as partes antes da existência do eventual processo. Apesar de não ser recorrente, tal instrumento pode ser interessante para empresas, fornecedores, prestadores de serviços e outros que não encontram na cláusula de arbitragem um caminho viável.

Sendo assim, estaria contemplada a possibilidade de celebrar, no âmbito das relações cíveis, acordos procedimentais e a disposição sobre as futuras posições processuais. No 
primeiro, as partes podem estipular mudanças procedimentais para adequar à realidade do caso concreto, inclusive, modificar a sequência de atos, a diminuição dos prazos, tipo de intimação, entre outros (GAJARDONI, 2008, p. 215). Entretanto o legislador vinculou tal possibilidade a uma correlação lógica entre a disposição celebrada e a necessidade do caso concreto (DONIZETTI, 2016, p. 448).

Deste modo, não havendo especificidade de causa que justifique a alteração procedimental, o juiz, responsável pelo controle dos negócios jurídicos processuais atípicos, deverá declarar que não há cabimento do acordo e anulá-lo (NEVES, 2016, p. 390).

A segunda, relacionada a posições processuais, determina que as partes podem negociar ônus, poderes, faculdades e deveres processuais, limitados à indisposição dos poderes-deveres do juiz, que não poderá ser objeto de deliberação, pois não podem as partes dispor de posição processual que não detém.

Entretanto, a doutrina problematiza a possibilidade de as partes impedirem, por meio da convenção processual, que o juiz determine a produção de prova de ofício, mas esta convenção recairia, em tese, sobre a vedação de dispor sobre posição processual que não possuem, sendo impossibilitado assim impedir que o juiz produza as provas que lhe sejam importantes para exaurir o mérito da demanda (NEVES, 2016, p. 392). Ao contrário do acordo procedimental, as partes são livres para dispor, dentro dos limites legais, sobre as posições processuais, não sendo vinculadas a justificativa lógica do caso concreto.

Considere-se que as partes tenham a prerrogativa de pactuar, no âmbito do processo ou anteriormente a existência dele, que não desejam produzir provas periciais, justificando a decisão conjunta no desejo que ambas compartilham de não inflar as despesas processuais. Neste cenário, considerando que a comprovação dos fatos e a produção de provas para tal é uma prerrogativa das partes, não seria razoável que as partes pudessem pactuar a não produção, por ambas, de provas periciais?

Certamente não faltarão vozes a defender a prerrogativa do juiz em produzir provas de ofício consubstanciada no art. 370 do CPC. No entanto, não poderiam as partes pactuar nesse sentido, mesmo que fosse mantida a prerrogativa do juiz em determinar a produção da prova mesmo diante do desinteresse das partes envolvidas? ${ }^{3}$

É verdade que as regras processuais possuem natureza pública e que a jurisdição é exercida pelo estado mediante condução do juiz. Todavia, , quando as relações entre as partes

\footnotetext{
${ }^{3}$ No contexto trazido, as partes que conjuntamente expressaram seu desinteresse na produção de prova pericial poderiam impugnar as despesas oriundas de uma prova que jamais desejaram produzir.
} 
envolvem direitos privados disponíveis, não parece razoável que elas possam decidir que espécie de provas produzirão em juízo?

São questionamentos que exigem profunda reflexão, e é correto dizer que, apesar de não autorizar expressamente nenhuma dessas possibilidades, o CPC/2015 abriu margem para que os negócios atípicos atinjam resultados mais significativos no âmbito das relações privadas que são discutidas dento do processo.

A cláusula geral do art. 190 do CPC 2015 permite as partes convencionem sobre ônus, poderes, faculdades e deveres, inclusive restringindo e delimitando de maneira expressa as hipóteses em que o juízo poderá anular a celebração, demonstrando a intencionalidade do legislador em não esvaziar e reduzir tal instituto às hipóteses previstas em lei. Todavia, a concretização de negócios jurídicos processuais atípicos deve observar requisitos expressos, tais como a obrigatoriedade de que os processos admitam a autocomposição e os previstos para validade do negócio jurídico em conformidade com o art. 104 do Código Civil.

A capacidade de que trata o Código Civil deve ser material e processual, ou seja, a celebração de negócios processuais atípicos exige que as partes tenham capacidade em juízo e capacidade material, de modo que os relativa ou absolutamente incapazes, ainda que devidamente assistidos ou representados, não poderiam celebrar. O objeto lícito corresponde ao procedimento e posições processuais das partes e a forma deverá ser escrita, apesar da possibilidade de admissão de forma oral, a escrita atribui maior previsibilidade e segurança jurídica (NEVES, 2016, p. 394).

A anulabilidade do negócio jurídico processual atípico, a cargo do juízo, recairá nas situações de inobservância dos requisitos materiais do artigo 104 do Código Civil e do formais previstos no artigo 190 do Código de Processo Civil. Ainda, será nulo se for meramente simulado (art. 167 do CC) ou contiver vícios sociais ou de consentimento.

Neste sentido, a análise de anulabilidade deverá ser realizada à luz do princípio constitucional da boa-fé objetiva, ou seja, não haverá nulidade sem prejuízo (ALMEIDA, 2014, p. 124), de modo que "o controle dos requisitos objetivos e subjetivos de validade da convenção de procedimento deve ser conjugado com a regra segundo a qual não há invalidade do ato sem prejuízo", conforme enunciado 16 do Fórum Permanente de Processualistas Civis. O juiz deverá verificar abuso no exercício do direito de autorregramento da vontade das partes, constante no direito de celebração de negócios jurídicos processuais atípicos.

Outras duas hipóteses de anulabilidade são: a) a inserção de cláusula abusiva em contrato de adesão, de modo que o juízo verificará a presença de regras isonômicas, que tratem aderente e responsável de igual forma na elaboração do contrato, todavia sendo vedado ao juiz 
anular tal cláusula inaudita altera parte, com fulcro no princípio constitucional de contraditório; b) situação de vulnerabilidade processual, ou seja, a limitação pessoal involuntária de caráter permanente ou provisório, ensejada por fatores econômicos, sanitários, organizacionais ou técnicos.

Sendo assim, o negócio jurídico processual será nulo desde que o objeto imponha um sacrifício injustificado a uma parte vulnerável. "Há indício de vulnerabilidade quando a parte celebra acordo de procedimento sem assistência técnica-jurídica", conforme o enunciado $\mathrm{n}^{\circ} 18$ do Fórum Permanente de Processualistas Civis.

Entretanto, ao criar mudança procedimental de acordo com as especificidades da causa, o legislador não consagrou a livre vontade das partes, mas uma vontade justificada e condicionada. Não se pode olvidar que o processo é instituto de ordem pública que implica diretamente na qualidade da prestação jurisdicional.

Desta forma, o que se advoga é a ampliação da celebração dos negócios jurídicos processuais atípicos, devidamente limitados pelas normas processuais e materiais cogentes, instrumento fundamental para ampliação do controle dos atos processuais pelas partes no sistema processual civil brasileiro.

\section{Considerações finais}

A possibilidade de celebração de negócios jurídicos processuais caracteriza um processo de democratização e de autonomia da vontade do processo civil, de modo que os litigantes são inseridos no procedimento de maneira ativa e convencionam sobre ônus, faculdades, poderes e deveres processuais, adequando o procedimento as especificidades do caso concreto.

Neste aspecto, vislumbra-se a influência do princípio da autonomia privada no caráter publicista do processo civil, demonstrando a necessária relativização da dicotomia entre o direito público e o direito privado no ordenamento jurídico brasileiro. Não significa que a regulamentação processual perderá seu caráter publicista, mas apenas que contará com institutos mais liberais dentro de um ambiente restrito e controlado.

O processo de constitucionalização do direito processual civil brasileiro implica na releitura dos institutos tradicionais à luz da axiologia constitucional, de modo que o processo contemple a dignidade da pessoa humana e a igualdade, assim como o contraditório, a ampla defesa, a eficiência, a primazia de mérito e o acesso à justiça. Neste ínterim, os negócios jurídicos processuais e a participação das partes corroboram para a concretização dos valores constitucionais. 
Deste modo, observando os pressupostos do art. 190 do Código de Processo Civil, em consonância com requisitos de validade do negócio jurídico do art. 104 do Código Civil e as restrições que o juízo poderá impor à celebração dos negócios jurídicos processuais atípicos, os litigantes devem valer-se dessa possibilidade jurídica a fim de estabelecer efetividade e garantir uma prestação jurisdicional mais adequada à realidade do caso concreto, consolidando a democratização e constitucionalização do direito processual civil.

\section{Referências}

ALMEIDA, Diogo Assumpção Rezende. Das convenções processuais no processo civil. Tese (Doutorado em Direito Processual) - Faculdade de Direito, Universidade do Estado do Rio de Janeiro, Rio de Janeiro, 2014.

AMARAL, Francisco. Direito civil: introdução. 6. ed. Rio de Janeiro: Renovar, 2012.

BAUMAN, Zygmunt. Modernidade líquida. Rio de Janeiro: Jorge Zahar, 2001.

BORGES, Roxana Cardoso Brasileiro. Disponibilidade dos direitos de personalidade e autonomia privada. São Paulo: Saraiva, 2005.

BRASIL. Constituição da República Federativa do Brasil. Disponível em: https://www.senado.leg.br/atividade/const/con1988/con1988_14.12.2017/art_60_.asp. Acesso em: 17 abr. 2020.

BRASIL. Lei no 13.105, de 16 de março de 2015. Código de Processo Civil. Diário Oficial da República Federativa do Brasil. Brasília, DF: 10 jan. 2002. Disponível em:

http://www.planalto.gov.br/ccivil_03/_ato2015-2018/2015/lei/113105.htm. Acesso em: 18 abr. 2020.

CABRAL, Antonio do Passo. Convenções processuais: entre publicismo e privatismo. Tese de Livre-docência. São Paulo: Universidade de São Paulo, Faculdade de Direito, 2015.

CUNHA, Leonardo Carneiro da. Negócios jurídicos processuais no processo civil brasileiro. In: CABRAL, A. do P.; NOGUEIRA, P. H. (cords.). Negócios processuais. Salvador: JusPodivm, 2016.

DIDIER JUNIOR, Fredie. Curso de direito processual civil. 17. ed., v. 1, Salvador: JusPodivm, 2016.

DIDIER JÚNIOR, Fredie. Princípio do respeito ao autorregramento da vontade no processo civil. In: CABRAL, A. do P.; NOGUEIRA, P. H. (cords.). Negócios processuais. Salvador: JusPodivm, 2015.

DINAMARCO, Cândido Rangel; LOPES, Bruno Vasconcelos Carrilho. Teoria geral do novo processo civil. 4. ed. São Paulo: Malheiros, 2019.

FERRI, Luigi. La autonomía privada. Tradução: Luis Sancho Mendizábal. Granada: 
Editorial Comares, 2001.

GAJARDONI, Fernando da Fonseca. Flexibilização procedimental: um novo enfoque para o estudo do procedimento em matéria processual. São Paulo: Atlas, 2008.

GRINOVER, Ada Pellegrini; CINTRA, Antônio Carlos de Araújo; DINAMARCO, Cândido Rangel. Teoria geral do processo. 24. ed. São Paulo: Malheiros, 2008.

LAKATOS, Eva Maria; MARCONI, Marina de Andrade. Fundamentos de metodologia científica. São Paulo: Atlas, 2009.

LIMA, Jairo Néia. CAMBI, Eduardo. Constitucionalização do direito privado. In: Acesso à justiça e os direitos da personalidade. Dirceu Pereira Siqueira, Ivan Aparecido Ruiz, organizadores. 1. ed. Birigui: Boreal, 2015.

MARTINS-COSTA, Judith. A boa-fé no direito privado: sistema e tópica no processo obrigacional. São Paulo: Revista dos Tribunais, 1999.

MEDINA, José Miguel Garcia. Novo código de processo civil comentado: com remissões e notas comparativas ao CPC/1973. 5. ed. São Paulo: Revista dos Tribunais, 2017.

MIRANDA, Pontes de. Tratado de direito privado: parte geral. Rio de Janeiro: Borsoi, 1954.

MOREIRA, José Carlos Barbosa. Convenção das partes sobre matéria processual. Revista de Processo, São Paulo, v. 33, p. 182-191, jan./mar. 1984. Disponível em:

http://migre.me/wGEIa. Acesso em: 19 abr. 2020.

NERY JUNIOR, Nelson. Princípios do processo civil na Constituição Federal. 3. ed. São Paulo: Revista dos Tribunais, 1996.

NEVES, Daniel Amorim Assumpção. Manual de direito processual civil: volume único. 8 . ed. Salvador: JusPodivm, 2016.

NOGUEIRA, Pedro Henrique. Negócios jurídicos processuais. Salvador: Juspodivm, 2016.

PERLINGIERI, Pietro. Perfis do direito civil: introdução ao direito civil constitucional. Trad. Maria Cristina de Cicco. 3. ed. Rio de Janeiro: Renovar, 2002.

PONTE, Marcelo Dias. Negócio jurídico processual e flexibilização do procedimento: as influências da autonomia privada no paradigma publicista do direito processual civil. Revista Eletrônica de Direito Processual - REDP. Volume 16. Julho a dezembro de 2015 Disponível em: https://www.e-publicacoes.uerj.br/index.php/redp/index. Acesso em: 14 abr. 2020.

REDONDO, Bruno Garcia. Negócios processuais: necessidade de rompimento radical com o Sistema do CPC/73 para a adequada compreensão da inovação do CPC/2015. In: CABRAL, A. do P.; NOGUEIRA, P. H. (cords.). Negócios processuais. Salvador: JusPodivm, 2015.

SCHREIBER, Anderson. Manual de direito civil contemporâneo. São Paulo, Saraiva, 2019. 
TAVARES, André Ramos. Fronteiras da hermenêutica constitucional. Coleção Professor Gilmar Mendes. São Paulo: Editora Método, 2006.

WAMBIER, Teresa Arruda Alvim; CONCEIÇÃO, Maria Lucia Lins; RIBEIRO; Leonardo Ferres da Silva; e MELLO, Rogério Licastro Torres de. Primeiros comentários ao novo código de processo civil. São Paulo: Revista dos Tribunais, 2016. 